\title{
REPOSISI PEMBELAJARAN SEJARAH LOKAL DALAM MENGHADAPI ERA GLOBAL
}

\author{
Hamdan Tri Atmaja \\ Email : atmaja.hta@gmail.com \\ Jurusan Sejarah Fakultas Ilmu Sosial Universitas Negeri Semarang
}

\begin{abstract}
Abstrak
Selain orang-orang besar atau The Big Man, narasi sejarah Indonesia masih berkutat pada upaya membangun nasionalisme warga negara. Padahal saat ini, di tengah perubahan sosial yang begitu cepat berlangsung, aspek-aspek karakteristik masyarakat semakin banyak yang perlu dikuatkan, seperti empati, kearifan, kecerdasan ekologi, keserdasan sosial, intelegensia politik, dan banyak lagi. Gagasan penting yang coba ditawarkan melalui artikel ini adalah 1) dominasi narasi politik dalam kurikulum sejarah terasa kering, konsekueni dari itu adalah tersingkirnya materi bercorak lokalitas dari struktur kurikulum yang sebenarnya memerlukan keragaman perspektif dan kajian; 2) perlunya memperhatikan keragaman sejarah lokal sebagai sumber pembelajaran yang lebih dinamis dan memungkinkan diskursus baru bagi pembelajaran di sekolah; dan 3) sejarah lokal perlu direposisi untuk mendapatkan bentuk yang lebih ideal dalam kurikulum sejarah. Sehingga pembelajaran sejarah akan lebih menarik dan mampu menjawab tantangan di era global.
\end{abstract}

Kata Kunci: Sejarah Lokal, Reposisi, pembelajaran, era global

\section{Pendahuluan}

Sejarah dan pembelajaran sejarah adalah dua hal yang berbeda. Sejarah adalah faktafakta masa lampau yang telah diuji kebenarannya dan membangun sebuah narasi masa lampau sedang pendidikan sejarah adalah fakta-fakta masa lampau yang dikemas untuk kepentingan pendidikan. Berdasarkan pada narasi tersebut di atas ada tujuan yang berbeda, sejarah lebih mementingkan penggalian peristiwa masa lampau dengan prosedur keilmuan atau kaidah-kaidah penulisan sejarah, sementara itu Pendidkan sejarah lebih menekankan pada penanaman nilai pada peserta didik melalui peristiwa sejarah. Penggalian peristiwa masa lampau dilakukan oleh para sejarawan melalui kegiatan penelitian dan keberlangsungan pembelajaran sejarah diperankan oleh guru sejarah di ruang-ruang kelas dengan peserta didik sebagai objek sasarannya.Widja (1991: 23) dalam bukunya Sejarah Lokal: Suatu Perspektif dalam Pengajaran Sejarahmenyatakan bahwa pembelajaran sejarah adalah perpaduan antara aktivitas belajar dan mengajar yang di dalamnya mempelajari tentang peristiwa masa lampau yang erat kaitannya dengan masa kini. Berdasarkan pendapat Widja tersebut dapat ditarik sebuah kesimpulan jika 
mata pelajaran sejarah merupakan bidang studi yang terkait dengan fakta-fakta dalam kajian sejarah namun tetap memperhatikan tujuan pendidikan pada umumnya.

Pembelajaran sejarah yang berlangsung di ruang kelas, tidak bertujuan untuk mencetak para ilmuwan sejarah, tetapi lebih berorientasi pada membangun sebuah kesadaran siswa yang berujung pada perubahan perilaku siswa. Kesadaran yang ditanamkan diantaranya adalah kesadaran akan perjuangan dan perjalanan bangsanya, kesadaran untuk melestarikan bendabenda peninggalan sejarah, kesadaran untuk melestarikan kearifan lokal pada masing-masing daerah, dan kesadaran untuk mengambil hikmah dari peristiwa sejarah serta kesadaran untuk mengamalkan nilai-nilai kebangsaan dalam upaya memperkuat dan mempertahakan Negara Kesatuan Republik Indonesia (NKRI).Kartodirdjo (1993:258) menyatakan peranan strategis pengajaran sejarah dalam rangka pembangunan bangsa menuntut suatu penyelenggaran pengajaran sejarah sebagai pemahaman dan penyadaran, sehingga mampu membangkitkan semangat pengabdian yang tinggi, penuh rasa tanggung jawab serta kewajiban. Kepekaannya terhadap sejarah akan melahirkan aspirasi dan inspirasi untuk melaksanakan tugasnya sebagai warga negara yang baik.

Hasan (2012: 35) menjelaskan dua tujuan penting pembelajaran sejarah, pertama sebagai media yang mampu mengembangkan potensi siswa untuk mengenal jati diri bangsanya. Kedua sebagai wahana pendidikan untuk mengembangkan disiplin ilmu sejarah. Selain itu Hunt (2007: 7) secara lebih rinci menjelaskan hasil dari History Working Group, ada sembilan tujuan dari pembelajaran sejarah di sekolah, diantaranya adalah: (i) untuk memahami masa kini dalam konteks masa lalu; (ii) untuk membangkitkan minat berdasarkan masa lalu; (iii) untuk menanamkan identitas bagi para siswa (kebangsaan); (iv) untuk memberikan pemahaman kepada siswatentang akar dan warisan budaya mereka; (v) memberikan pengetahuan kepada siswa tentang negara dan kebudayaan dalam dunia modern; (vi) untuk melatih pikiran dengan studi disiplin ilmu sejarah; (vii) untuk memperkenalkan siswa metodologi sejarah yang khas; (viii) untuk mendorong bagian lain dari kurikulum; dan (ix) untuk mempersiapkan siswa menuju kehidupan dewasa.

Berlandaskan pada tujuan yang ketiga dan empat, peninggalan sejarah dan warisan budaya sebagai bukti peradaban bangsa Indonesia dapat digunakan sebagai media untuk membangkitkankesadaran untuk melestarikan kearifan lokal di masing-masing daerah. Maka dari 
itu materi pembelajaran sejarah Indonesia yang disajikan di ruang kelas seharusnya tidak hanya berfokus pada peristiwa-peristiwa sejarah yang dianggap sebagai puncak-puncak sejarah nasional, tetapi materi sejarah juga harus memuat materi sejarah lokal untuk masing-masing wilayah. Pentingnya sejarah lokal diberikan dalam pembelajaran sejarah adalah untuk melestarikan peradaban dan kebudayaan pada masing-masing suku bangsa yang ada di Indonesia. Melalui sejarah lokal siswa dapat mengetahui asal usul dan akar sejarahnya, sejarah lokal juga dapat digunakan untuk memahami dinamika masyarakat pada tingkat lokal dan melalui sejarah lokal siswa dapat mengetahui habitus kehidupan nenek moyang dari waktu ke waktu.

Realita di lapangan menunjukkan, keberadaan sejarah lokal dalam kurikulum sejarah nasional, masih belum menduduki posisi yang strategis. Sejarah lokal masih dianggap sebagai konten yang tidak terlalu dibutuhkan dalam kurikulum sejarah. Bahkan keberadaannya sering disikapi secara apriori sebagai sebuah materi yang tidak memberikan dampak apa-apa pada siswa. Abdullah (dalam Mulyana dan Gunawan, 2007: 2) menjelaskan bahwa sejarah lokal dalam konteks pembelajaran di sekolah sejatinya tidak dibatasi dari segi administrasi keruangan. Aspek keruangan dibatasi oleh penulis sejarah, mencakup lingkungan sekitar (neighborhood) dengan studi masyarakat dalam seluruh aspek kehidupan. Dalam konteks menumbuhkan identitas, materi-materi yang bersifat lokal juga penting dimanfaatkan. Mengingat di dalam materi tersebut banyak terselip kearifan yang penting ditanamkan ke siswa.

Materi sejarah lokal akan semakin menarik jika guru mampu menyampaikannya secara kreatif, tentunya kreatifitas guru dapat ditopang dengan memanfaatkan berbagai macam media pembelajaran sejarah seperti infografis, poster, maupun film dokumenter. Perubahan masyarakat yang terkait dengan mentalitas dan bagaimana masyarakat memahami jati diri mereka dalam lingkungannya, meliputi aspek busana, musik, ritus-ritus agama juga dapat dikaji (Mulyana dan Gunawan, 2007: 4-5). Dalam konteks itu, sejarah nasional yang lebih dominan dalam kurikulum sejarah sejatinya hanya merupakan representasi politis dari sejarah lokal (Margana dan Widyafitriningsih, 2010: 495).

Sejarah nasional yang berkembang pesat pada masa awal kemerdekan telah menjadikan historiografi Indonesia bersifat nasional-sentris. Sehingga perspektif nasionalisme lama yang politis terbawa dan terwariskan dari generasi ke generasi. Sementara itu, sejarah lokal masih 
berada di wilayah margin, jarang diperhatikan, dan menjadi objek kajian yang hambar, baik oleh kalangan peneliti maupun guru sejarah. Di balik itu, elastisitas sejarah lokal mampu menghadirkan berbagai fenomena, baik berkaitan mulai dari latar belakang keluarga (family history), sejarah sosial dalam lingkup lokal, peranan pahlawan lokal dalam perjuangan lokal maupun nasional, kebudayaan lokal, asal-usul suatu etnis dan berbagai peristiwa yang terjadi dalam tingkat lokal.

Sejarah lokal sendiri menurut, Brooks (2008: 1) yaitu sejarah yang lebih banyak berbicara tentang masyarakat kecil, tempat, institusi, komunitas dan biasanya objek sejarah lokal sangat dekat dengan kehidupan masyarakat di dalam satu arena. Di Indonesia sendiri sebenarnya kajian tentang sejarah lokal berkembang dengan sangat baik dan pesat. Hampir di setiap-setiap universitas maupun komunitas kesejarahan, orang-orang yang konsen memperhatikan keberadaan sejarah lokal tidak begitu sulit ditemukan. Bahkan, belakangan ini dengan maraknya pemberitaan tentang revitalisasi-revitalisasi peninggalan sejarah di berbagai daerah, sejarah lokal kembali muncul sebagai primadona baru di panggung historiografi Indonesia. Namun demikian, kemajuan dalam bidang kajian itu sama sekali tidak berimplikasi positif terhadap posisi sejarah lokal dalam kurikulum. Meskipun sebenarnya Kurikulum 2013 memberikan peluang bagi guru untuk menyelipkan materi sejarah lokal dalam setiap pembahasan tentang materi sejarah nasional di kelas.

Tulisan ini ingin secara terbuka mengkritik kurikulum sejarah dan pelaksanaannya yang dewasa ini masih belum memberikan ruang yang luas bagi materi-materi bertemakan lokalitas. Sejarah seolah-olah hanya berfungsi dan bermanfaat untuk menumbuhkan nasionalisme siswa. Padahal lebih jauh, sejarah menurut Ibnu Khaldun seharusnya dapat memberikan hikmah mendalam bagi setiap insan manusia. Dengan kata lain, di Abad 21 ini pembelajaran sejarah harus mengarahkan tujuannya bukan lagi ke arah membangun kesadaran dan nasionalisme semata, melainkan aspek-aspek lain seperti; empati, kebijaksanaan, kebanggaan pada budaya daerah, pemaknaan nasionalisme yang tidak sempit, patriotisme dalam konteks milenial juga menjadi celah yang perlu diisi oleh muatan pembelajaran sejarah. Maka dari itu, sejarah lokal secara praksis harus dipertimbangkan oleh para pendidik untuk dimasukan ke dalam kurikulum sejarah dengan konseptualisasi yang jelas, sehingga para pelaksana kurikulum itu, dalam hal ini guru tidak merasa bingung dan canggung untuk mengajarkan sejarah lokal di dalam kelas. 


\section{Dominasi Historiografi Politik dalam Kurikulum Sejarah}

Kurikulum sejarah saat ini telah memaksa guru untuk mengajarkan sejarah secara sporadis. Perjalanan panjang bangsa Indonesia sejak zaman pra-aksara hingga kontemporer termaktub dalam kurikulum, dan siswa diminta untuk mempelajari semuanya. Dalam hal ini aspek multikultural dalam konteks historis tidak pernah diperhitungkan. Indonesia sebagai negara yang terbentang luas dari Sabang hingga Merauke tentu memiliki sejarah yang tidak sepenuhnya seragam, hal ini yang luput diperhatikan dalam penyusunan kurikulum sejarah untuk pembelajaran di sekolah, sehingga konstruksi materi yang ada terkesan tidak kontekstual. Misalnya, materi tentang kerajaan-kerajaan di Nusantara, sejarah mencatat bahwa tidak semua daerah atau wilayah di Nusantara ini yang sepenuhnya pernah mendapatkan pengaruh dari kerajaan-kerajaan itu, tetapi kurikulum memaksakan hal itu untuk mau-tidak mau harus dipahami oleh semua warga negara. Dampaknya adalah, ada bias pengetahuan tentang hal itu, siswa-siswa di Papua akan merasa aneh jika mempelajari kerajaan Mataram secara mendetail, sedangkan mereka tidak pernah merasakan pengaruh dari kerajaan tersebut. Oleh sebab itu, materi-materi tentang kerajaan itu sebaiknya diminimalisir sebagai sebuah pengetahuan umum, bukan yang wajib diajarkan di kelas.

Selain itu, dalam kurikulum sejarah Indonesia sendiri narasi-narasi tentang orang-orang besar juga masih sangat dominan. Cerita-cerita tentang kehebatan Patih Gajah Mada hingga kebesaran seorang Soekarno masih menghiasi dan cenderung dominan di dalam materi sejarah Indonesia. Bahkan pembahasan tentang tokoh-tokoh itu masih cenderung mengkultuskan daripada membelajarkan. Materi-materi itu telah membentuk pengetahuan siswa tentang kemenangan dan popularitas sebagai tujuan hidup, mengingat orang-orang yang kalah masih diibaratkan sebagai "sampah sejarah" yang tidak pantas masuk ke arena pendidikan. Di sini, peran sejarah lokal cukup penting untuk mengisi celah tersebut. Tahun 1984 di Medan, diadakan Seminar Sejarah Lokal yang telah merumuskan acuan dalam kajian sejarah lokal, dicatat oleh Kuntowijoyo (1995: 121) sebagai berikut: (i) dinamika sejarah pedesaan; (ii) pendidikan sebagai faktor dinamisasi dan interaksi sosial; (iii) interaksi antar suku bangsa dalam masyarakat majemuk; (iv) revolusi nasional di tingkat lokal; dan (v) biografi tokoh lokal. Semuanya menjadi pembahasan yang menarik jika di bawa masuk ke dalam kelas sejarah. 
Sejarah nasional yang diajarkan sekarang ini lebih pantas dikatakan sebagai hasil keputusan politik daripada keputusan akademik. Penentuan masuknya sebuah materi dalam kurikulum sejarah didominasi oleh kuatnya pengaruh politik dari satu kelompok yang mengintervensi jalannya pembuatan kurikulum. Pada masa Orde Baru, kehebatan-kehebatan tokoh pembesar Orde Baru banyak menghiasi narasi sejarah nasional, misalnya yang paling kuat dan populer pada masa itu adalah Suharto. Selain itu, peristiwa-peristiwa yang dipilih untuk diajarkan juga cenderung politis, semangat militerisasi, anti komunisme dan proses desukarnoisasi adalah yang paling mendominasi (Purwanto, 2012: 430). Dari sana dapat dianalisis bahwa sebenarnya pada kasus Indonesia, aspek ideologi menjadi penentu pembentukan kurikulum sejarah, bahkan hal itu berlangsung hingga saat ini, atau secara eksplisit dapat dikatakan bahwa kurikulum sejarah nasional adalah bagian dari ekspresi ideologi penguasa dalam bentuk yang akademis.

Selain orang-orang besar atau The Big Man, narasi sejarah Indonesia masih berkutat pada upaya membangun nasionalisme warga negara. Padahal saat ini, di tengah perubahan sosial yang begitu cepat berlangsung, aspek-aspek karakteristik masyarakat semakin banyak yang perlu dikuatkan, seperti empati, kearifan, kecerdasan ekologi, keserdasan sosial, intelegensia politik, dan banyak lagi. Sejarah lokal yang dinamis berpotensi untuk menumbuhkan itu semua jika kurikulum sejarah mau memberikan ruang bagi masuknya materi-materi bertemakan lokalitas ke dalam kelas sejarah. Selain itu, untuk mendukung pelaksanaanya, guru juga perlu terus melakukan upgrade informasi demi menjaga aktualitas pribadi guru, sehingga dalam proses pembelajarannya guru akan tampil maksimal untuk menjelaskan dua perspektif sejarah yang coba di tawarkan untuk pembentukan kurikulum sejarah nasional di masa depan, yaitu sejarah lokal untuk membentuk identitas dan disambung oleh sejarah nasional untuk membentuk rasa nasionalisme dan semangat kebangsaan.

\section{Ragam Kajian Sejarah Lokal untuk Pendidikan Sejarah}

Komplektisitas kajian sejarah lokal akan memperkaya materi sejarah untuk pembelajaran. Seperti dijelaskan di bab sebelumnya, dominasi historiografi yang bercorak politik saat ini perlu digeser ke arah historiografi yang lebih populis. Sejarah yang dekat dengan masyarakat, sehingga bukan hanya nasionalisme yang terbentuk, tapi siswa juga mengetahui akar budayanya. Sejarah yang dekat dengan masyarakat meliputi kajian seputar sejarah desa dari berbagai macam aspek, misalnya Djoko Suryo (1989) pernah mengkaji tentang sejarah sosial pedesaan di Karesidenan 
Semarang 1830-1900. Kajian itu merupakan kajian ilmiah yang dapat dimanfaatkan untuk keperluan praksis pendidikan, sehingga guru tidak lagi direpotkan dengan mempersiapkan segala macam kebutuhan materi ajar. Dinamika pedesaan yang diceritakan Suryo dalam bukunya itu banyak sekali mengungkap aspek-aspek sosial kemasyarakat di Jawa dari pola interaksi hingga struktur masyarakatnya.

Interaksi antar suku bangsa dalam masyarakat majemuk juga menjadi determinasi dalam kajian sejarah lokal yang sulit ditemukan dalam narasi-narasi sejarah nasional. Misalnya tentang interaksi etnis Cina-Jawa di berbagai daerah yang sangat jarang di singgung dalam sejarah nasional, konflik-konflik antar etnis dalam pembelajaran sejarah lebih sering dikaji menggunakan pendekatan resolusi konflik, padahal dalam sejarah, setiap narasi perlu dibaca secara kritis, mendalam, dan kronologis. Sejarah nasional selama ini jarang berbicara tentang kondisi sosial yang harmonis dalam pergumulan antar etnis di level lokal. Padahal kajian-kajian tentang interaksi antar etnis seperti yang dilakukan oleh Ong Hok Ham dan Leo Suryadinata dapat dijadikan rujukan untuk mengajarkan hal itu dalam kelas sejarah. Oleh sebab itu, materi sejarah nasional perlu diperkaya dengan muatan multikultural dalam bentuk interaksi antar etnis untuk mengajarkan kepada siswa pentingnya menjaga ikatan persaudaraan sesama anak bangsa dan toleransi antar etnis, agama, dan ras perlu terus dirawat untuk kebhinekaan Indonesia yang utuh.

Hasil kajian revolusi nasional di level lokal juga menjadi materi yang menarik dalam pembelajaran sejarah. Misalnya tentang Bandung Awal Revolusi 1945-1946 karya R.W. Smail, Revolusi di Surakarta karya Suyatno Kartodirdjo, Peristiwa Tiga Daerah: Revolusi dalam Revolusi hasil penelitian Anton Lucas, ketiga karya tersebut merupakan contoh kajian revolusi di level lokal yang dapat dijadikan materi untuk pembelajaran sejarah. Dalam materi itu, misalnya pada kajian milik Anton Lucas, revolusi tidak hanya dipandang dari peranan elit semata, melainkan sebenarnya revolusi di berbagai daerah Indonesia bergerak karena pengaruh orangorang kecil. Jika materi tersebut juga masuk ke dalam kelas sejarah, maka revolusi tidak lagi dipandang sebagai proses besar yang digerakan oleh orang-orang besar, melainkan, orang-orang kecil juga punya tempat dalam sejarah revolusi nasional Indonesia. Dan semua jasa-jasanya perlu dihargai dalam konteks kebangsaan. Proses penghargaan itulah yang akan menumbuhkan sikap arif pada siswa serta empati kepada masa lalu bangsanya, sehingga dikemudian hari peristiwa serupa tidak boleh terjadi lagi.

629 | Seminar Nasional Sejarah ke 4 Jurusan Pendidikan Sejarah Universitas Negeri Padang 
Kajian sejarah lokal yang juga penting diajarkan di kelas sejarah yaitu biografi tokoh lokal. Materi ini secara khusus akan memberikan keseimbangan bagi historiografi di dalam buku teks, mengingat saat ini dominasi The Big Man masih sangat kuat dalam sejarah Indonesia. Prinsip utama dari masuknya materi tokoh lokal adalah sejarah sebagai sebuah mosaik perlu melibatkan tokoh lokal dalam membangun heroisme bagi siswa, jadi bukan hanya orang-orang besar seperti Sudirman, Soekarno, Hatta, Ki Hajar Dewantara, dll. Tetapi tokoh lokal yang hidup dalam lingkup kecil di daerah, dengan peranan dan pengaruhnya juga perlu diangkat kisah-kisah inspirasinya ke dalam sebuah materi sejarah lokal yang dapat diajarkan di kelas sejarah. Tokoh lokal yang dianggap layak masuk ke dalam kelas sejarah misalnya, Oei Tiong Ham, yang dijuluki sebagai Raja Gula di Asia Tenggara dari Semarang, kisah inspiratif dari tokoh tersebut adalah kesuksesannya mengelola bisnis gula yang berhasil memperkerjakan ribuan orang. Selain itu ia juga salah satu tokoh yang berhasil mendesak pemerintah kolonial Hindia-Belanda untuk menghapuskan kebijakan Tauchang (Kucir Rambut) bagi masyarakat Tionghoa yang diberlakukan pasca Geger Pacinan tahun 1740. Selain itu adapula biografi Siti Manggopoh dari Sumantera Barat. Pada 1908, Siti melakukan perlawanan terhadap kebijakan ekonomi Belanda yaitu pajak uang (belasting). Peraturan belasting dianggap bertentangan dengan adat Minangkabau, karena tanah adalah milik komunal atau kaum dalam kebudayaan Minangkabau. Kedua tokoh tersebut adalah contoh kasus biografi tokoh yang dapat dijadikan sebagai materi ajar di kelas. Pada prinsipnya, materi biografi tokoh lokal akan memberikan pengalaman hidup yang inspiratif pada siswa, dengan belajar itu siswa dapat memahami akar budaya yang membentuk orang-orang hebat di sekitar tempat tinggal mereka.

Materi sejarah lokal pada prinsipnya sudah sudah memuat nilai kearifan lokal sebagai substansi yang perlu dipahami oleh siswa. Jacquesson, dkk (2012: 3) menjelaskan bahwa sejarah lokal lebih banyak berbicara tentang dimensi etika dan estetika, objek-objek kajian dalam sejarah lokal sedikit banyak diambil dari pengalaman-pengalaman berharga masyarakat. Dalam konteks pendidikan hal itu sangat sesuai diajarkan bagi siswa, mengingat tujuan pendidikan sendiri adalah membentuk masyarakat yang beretika dan menjunjung nilai-nilai luhur bangsanya. Sejarah lokal mampu menjadi media untuk mengangkat moralitas suatu masyarakat untuk disajikan dalam sebuah pengetahuan. Pengetahuan itu diproses sedemikian rupa untuk disampaikan dalam bentuk kearifan, sehingga siswa mampu memahami akar budayanya, memahami lingkungan sejarahnya, dan lebih jauh siswa dapat memahami identitas sosialnya. 630 | Seminar Nasional Sejarah ke 4 Jurusan Pendidikan Sejarah Universitas Negeri Padang 
Identitas sosial itu merupakan modal utama dalam membangun bangsa yang beradab (Yunus, 2016: 74).

\section{Reposisi Sejarah Lokal untuk Pembelajaran}

Sejarah lokal memang tidak sepenuhnya berdiri sendiri terpisah dengan narasi sejarah nasional. Setiap pembahasan sejarah lokal selalu terpaut dengan peristiwa-peristiwa besar seputar sejarah nasional. Oleh karena itu keduanya tidak dapat dipisahkan sebagai inter-section dalam historiografi Indonesia. Singer, dkk (2003: 66) dalam sebuah kumpulan tulisan bertajuk Teaching Local History menjelaskan bahwa sejarah lokal penting dimasukan ke dalam kurikulum secara khusus supaya pembelajaran sejarah tidak terlalu bersifat politis, pembelajaran sejarah lokal akan mengajarkan sesuatu yang lebih manusiawi, hal ini dipengaruhi oleh faktor geografis, yaitu kedekatan siswa dengan lingkungan sejarahnya. Kurikulum sejarah yang baik adalah yang mampu menempatkan sejarah lokal secara proporsional di dalamnya. Penerimaan sejarah lokal oleh siswa juga positif, dengan menggunakan pendekatan tematis, pembelajaran sejarah lokal akan semakin asyik dan menyenangkan. Sebenarnya dalam konteks pembelajaran, pendekatan tematis ini bisa dimulai dari guru, gaya dan sistem pembelajaran yang diterapkan guru untuk Kurikulum 2013 memungkinkan untuk mengeksplorasi sejarah lokal dalam kelas sejarah. Namun, catatan dalam hal ini adalah wawasan kelokalan dan analisis guru harus luas dan tajam, supaya penangkapan tentang fenomena kesejarahan dapat berlangsung secara akademis dan kritis.

Mulyana dan Gunawan (2007: 32) menjelaskan bahwa sebenarnya upaya memasukan sejarah lokal ke dalam kurikulum sudah lama dilakukan, namun karena kepentingan politik yang begitu kuat di dalam historiografi buku teks maka hal itu urung dilaksanakan. Masalah semacam inilah yang membuat sejarah lokal tidak eksis di kancah pendidikan, meskipun bagi para pengembang ilmu pengetahuan dan peneliti sejarah, kajian sejarah lokal saat ini tengah menanjak, dan diibaratkan sebagai "Primadona" dalam historiografi Indonesia. Kurikulum yang begitu kaku dan cenderung politis itu yang sulit ditembus oleh kalangan idealis untuk dapat memasukan materi sejarah lokal, padahal kebutuhan tentang materi tersebut bagi bangsa yang sedang mengalami krisis identitas sangatlah besar. Historiografi Indonesia seperti dijelaskan oleh Purwanto dan Adam (2005: 45) lebih banyak mengangkat kisah-kisah politik daripada kisah

kehidupan pada umumnya, historiografi masih menjadi mimbar bagi "Sang Pemenang" dan 
belum secara objektif mengangkat kisah-kisah orang-orang kecil yang juga memiliki pengaruh besar di daerah. Dalam konteks ini historiografi perlu berbenah, dari yang politis menuju etis dan estetis.

Pada saat ini sikap apriori terhadap sejarah lokal memang harus dikubur dalam-dalam. Kajian sejarah lokal banyak yang mengangkat kisah-kisah yang etis, atau bisa dikatakan sejarah lokal merupakan sejarah kehidupan yang sebenarnya. Widja (1991: 64) menjelaskan bahwa sebagai sejarah yang banyak mengangkat kisah etis, sejarah lokal dapat dimanfaatkan dalam pendidikan melalui dua jalur, yaitu politik kurikulum dan pembelajaran di kelas. Jalur politik kurikulum maksudnya, sejarah lokal dapat diangkat melalui kebijakan pusat terhadap kurikulum, kurikulum sejarah sudah sewajarnya memberikan ruang bagi materi-materi sejarah lokal, siswa akan lebih merasa dekat dengan lingkungan sejarahnya setelah mengikuti pembelajaran sejarah lokal. Namun hal ini menemui kendala ketika sejarah masih dijadikan sebagai panggung bagi penguasa untuk eksis dalam sejarah, tidak jarang eksistensi penguasa mengubur dalam-dalam eksistensi orang-orang kecil, peristiwa-peristiwa di daerah yang sebenarnya memiliki arti penting bagi masyarakat. Dalam hal ini yang harus turut berjuang untuk menyelesaikan masalah adalah akademisi dan politisi yang akademis, misi utamanya adalah menggeser dominasi sejarah politik dalam buku teks dan kurikulum. Berbeda dengan itu, sejarah lokal dapat dimanfaatkanmelalui jalur pembelajaran di kelas secara langsung, di sini peran guru ada di titik sentral, wawasan, intuisi, dan analisa menjadi penentu keberhasilan guru untuk mengajarkan sejarah lokal di kelas. Biasanya dalam hal ini guru menyelipkan materi sejarah lokal dalam setiap pembahasan yang dilakukan, kemampuan untuk mengaitkan konteks dengan teks adalah strategi analitik dalam pembelajaran sejarah.

Pasca Kurikulum 2013 ditetapkan sebenarnya peluang pembelajaran sejarah lokal lebih besar untuk dilaksanakan, kurikulum tersebut memberikan otonomi bagi guru untuk dapat mengelola kelas secara kreatif dan inovatif. Guru sepenuhnya berkuasa atas kelas dalam konteks pengelolaan, meskipun proses pembelajaran sendiri telah bergeser dari Teacher Centered ke Student Centered. Namun demikian, nomenklatur Sejarah Indonesia dan Sejarah Peminatan juga menjadi persoalan tersendiri dalam pelaksanaan di lapangan, selain bias, konsep tersebut juga menimbulkan banyak perdebatan di kalangan akademisi, sebenarnya yang paling sesuai untuk diterapkan adalah nomenklatur sejarah lokal dan sejarah nasional, selain lebih tegas, kedua 
konsep tersebut sangat familiar bagi guru, sehingga dalam inovasi dan aksinya guru dapat lebih sistematis menjelaskan apa itu sejarah dan apa guna sejarah.

Sejarah lokal memiliki determinasi yang tinggi untuk diajarkan di kelas sejarah, selain objek kajian yang luas dan dinamis, sejarah lokal juga memiliki muatan nilai kearifan lokal yang tidak dimiliki oleh narasi sejarah nasional dalam kurikulum. Kearifan lokal itu merupakan nilainilai yang mengendap lama di masyarakat dan saat ini keberadaannya terancam oleh pengaruh budaya pop dari Barat. Sejarah lokal memberikan pengalaman berharga bagi siswa, selain tematema unik yang akan diangkat, kisah-kisah tradisi dan sejarah lisan di daerah juga menjadi objek kajian yang menarik untuk pembelajaran. Sudah saatnya kurikulum sejarah memberikan ruang bagi sejarah lokal untuk dikembangkan dalam pembelajaran, Smith (1984: 215) menjelaskan bahwa sejarah lokal memiliki pengaruh yang besar dalam membendung pengaruh globalisasi, sejarah lokal memberikan landasan pengetahuan tentang sejarah, selain itu sejarah lokal juga mengajarkan kepada siswa tentang nilai-nilai kehidupan sebagai warga lokal. Koteks warga lokal ini yang jarang disinggung sehingga kini Indonesia tengah mengalami degradasi moral yang luar biasa karena meninggalkan konteks lokalitas itu. Sekarang, sudah saatnya sejarah lokal menjadi the rising stars untuk merubah keadaan pembelajaran sejarah yang selama ini masih cenderung politis dan elitis. Sejarah lokal merupakan bagian dari desakralisasi yang konkret, sejarah yang selama ini hanya menjadi panggung bagi pemenang harus digeser menjadi arena bagi sejarah kehidupan yang lebih luas.

\section{Simpulan}

Pembelajaran sejarah terlalu didominasi oleh narasi politik, sehingga proses pendidikan nampaknya tidak mampu berjalan sesuai dengan kaidah pedagogi. Hal ini dapat diamati melalui konstruksi kurikulum dan proses pendidikan yang berlangsung di lapangan. Dominasi narasi politik dalam pembelajaran sejarah membuat pendidikan sejarah menjadi beku dan tidak dinamis

untuk dipelajari, dampaknya pembelajaran sejarah menjadi kering inspirasi dan kurang kontekstual dengan keadaan di sekitar siswa. Ragam kajian sejarah yang telah disebutkan di atas menunjukkan bahwa sejarah lokal cukup relevan untuk diajarkan di sekolah, hingga saat ini belum ada upaya serius untuk dapat memasukkan materi sejarah lokal ke konstruksi kurikulum. Dibutuhkan reposisi yang akan menempatkan sejarah lokal ke struktur kurikulum yang akan memungkinkan sejarah lokal diajarkan secara sistematis di sekolah. Sehingga dominasi politik 633 | Seminar Nasional Sejarah ke 4 Jurusan Pendidikan Sejarah Universitas Negeri Padang 
yang ada pada pembelajaran sejarah sedikit demi sedikit akan terdegradasi, dan digantikan dengan materi yang lebih kontekstual dan mengena dihari siswa.

\section{DAFTAR PUSTAKA}

Brooks, Pamela. 2008. How To Research Local History. Oxford: How To Books.

Hasan, S. Hamid. 2012. Pendidikan Sejarah Indonesia: Isu dalam Ide dan Pembelajaran. Bandung: Rizqi Press

Hunt, Martin. 2007. A Practical Guide To Teaching History In The Secondary School. New York: Routledge

Jacquesson, S., dkk. 2012. Introduction Local History. London: Routledge.

Kartodirdjo, Sartono. 1993. Perspektif Ilmu Sosial dalam Metodologi Sejarah. Jakarta: Gramedia.

Kartodirdjo, Suyatno. 1982. Revolution in Surakarta 1945-50: A Case Study of City and Village in The Indonesian Revolution. Disertasi. Canberra: Australian National University.

Kuntowijoyo. 1995. Pengantar Ilmu Sejarah. Yogyakarta: Bentang.

Lucas, Anton E. 1989. Peristiwa Tiga Daerah: Revolusi dalam Revolusi. Jakarta: Pustaka Utama Grafiti

Mulyana, Agus, and Restu Gunawan. 2007. Sejarah Lokal Penulisan dan Pembelajaran di Sekolah. Bandung: Salamina

Purwanta, Hieronymus. 2012. "Evaluasi Isi Buku Teks Pelajaran Sejarah pada Masa Orde Baru." Cakrawala Pendidikan, Vol. 31, No. 3.

Purwanto, Bambang, and Asvi Warman Adam. 2005. Menggugat Historiografi Indonesia. Yogyakarta: Ombak

Singer, Alan (Edt.). 2003. “Teaching Local History.” Social Science Docket, Vol. 3, No. 2

Smail, J. R. W. 2011. Bandung Awal Revolusi: 1945-1946. Jakarta: Ka Bandung.

Smith, Carol A. 1984. "Local History in Global Context: Social and Economic Transitions in Western Guatemala." Comparative studies in society and history, Vol. 26, No.2

Sri Margana dan Widyafitriningsih. 2010. Sejarah Indonesia Perspektif Lokal dan Global. Yogyakarta: Ombak

Suryo, Djoko. 1989. Sejarah Sosial Pedesaan Karesidenan Semarang 1830-1900. Yogyakarta: PAU SS Universitas Gadjah Mada 634 | Seminar Nasional Sejarah ke 4 Jurusan Pendidikan Sejarah Universitas Negeri Padang 
Widja, I. G. 1991. Sejarah lokal suatu perspektif dalam pengajaran sejarah. Bandung: Penerbit Angkasa.

Yunus, Rasid. 2016. "Transformasi nilai-nilai budaya lokal sebagai upaya pembangunan karakter bangsa." Jurnal Penelitian Pendidikan, Vol. 13, No. 1 